\begin{tabular}{l|c|c}
\hline ISSN: 0001-5113 & ACTA ADRIAT., & SHORT COMMUNICATION \\
AADRAY & $59(2): 231-236,2018$ & \\
\hline \hline
\end{tabular}

DOI:10.32582/aa.59.2.9.

\title{
First records of Madeira rockfish Scorpaena maderensis (Osteichthyes: Scorpaenidae) from the Tunisian coast (central Mediterranean)
}

\author{
Sihem RAFRAFI-NOUIRA ${ }^{1 *}$, Daniel GOLANI ${ }^{2}$ and Christian CAPAPÉ ${ }^{3}$ \\ ${ }^{1}$ Laboratoire de Bio-surveillance de l'Environnement, Unité d'Hydrobiologie Littorale et \\ Limnique, Université de Carthage, Faculté des Sciences, Zarzouna, 7021 Bizerte, Tunisia \\ ${ }^{2}$ Department of Evolution, Ecology and Behaviour, The Hebrew University of Jerusalem, \\ 91904 Jerusalem, Israel \\ ${ }^{3}$ Laboratoire d'Ichtyologie, case 104, Université de Montpellier, \\ 34095 Montpellier cedex 5, France \\ *Corresponding author, e-mail: sihem.rafrafi@yahoo.fr
}

The authors present the first records of Madeira rockfish Scorpaena maderensis Valenciennes, 1833 from the Tunisian coast (central Mediterranean). The specimens are described including morphometric measurements and meristic counts. The origin of the species in its new living area is discussed and commented. However, these new findings confirm the establishment of a viable population of $\mathrm{S}$. maderensis in central Mediterranean.

Key words: Osteichthyes, Scorpaenidae, Scorpaena maderensis, Tunisia, population, central Mediterranean

\section{INTRODUCTION}

The Madeira rockfish Scorpaena maderensis Valenciennes, 1833 is distributed south of the Strait of Gibraltar from Morocco to the Gulf of Guinea, and in waters surrounding some islands such as Cape Verde, Canaries, Madeira and Azores (CADENAT, 1943; HUREAU \& LITVINENKO, 1986).

Scorpaena maderensis was first recorded in the Mediterranean Sea by KOLOMBATOVIĆ (1904), in the Croatian east part of the Adriatic Sea, from eastern Sicily by TORTONESE (1975), and new records were reported in the Adriatic Sea (DULČIĆ et al., 2003). Eastward, $S$. maderensis was recorded in the Turkish marine waters (BILECENOGLU et al., 2014), and the eastern Levant Basin (ESCHMEYER, 1969).

Scorpaena maderensis seems to have disappeared from the Italian waters during years 1990, conversely recent ecological studies indicated the species dominance in fish communities from rocky shores located in shallow coastal waters from the south-eastern coast of Sicily (LA MESA, 2005).

The species $S$. maderensis is rather abundant in the central Mediterranean and such occurrence was confirmed by a well-documented record from off Malta Island (FALZON, 2011), and also by two other records from the north- 


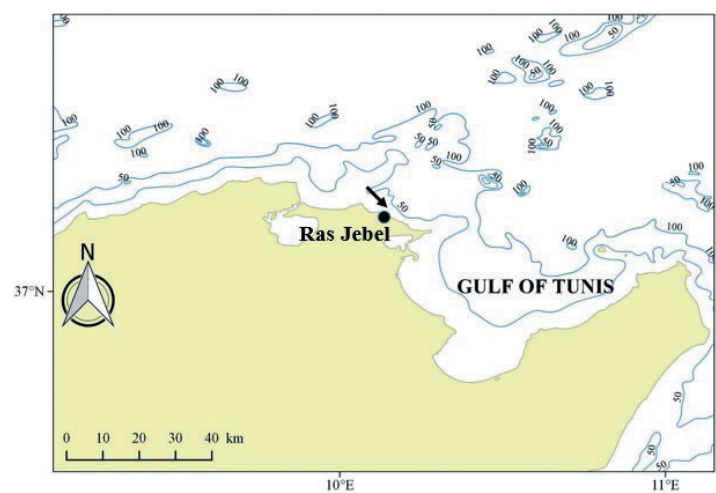

Fig.1. Map of northern Tunisia showing the capture site (black arrow) of Scorpaena maderensis

ern coast of Tunisia. These two latter records form the purpose of the present paper, and are described with comments on their distribution in the capture area and the Mediterranean Sea.

\section{MATERIAL AND METHODS}

Information on two captures Scorpaena maderensis was provided by local fishermen familiar with these fishing grounds. The help of

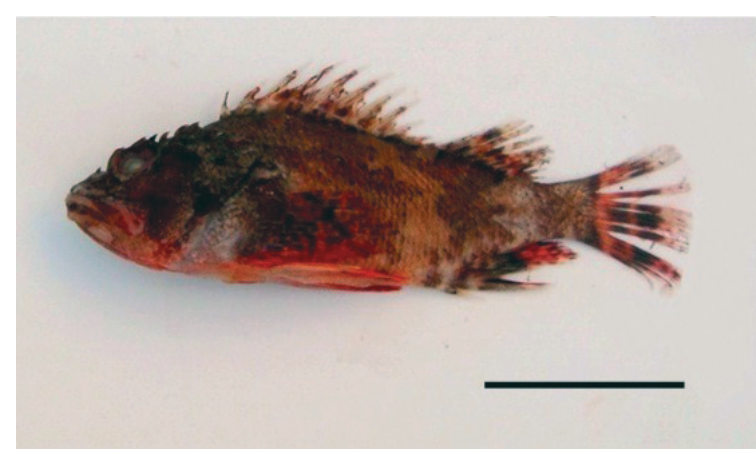

Fig.2. Scorpaena maderensis (FSB-Scor-mad 02), captured off northern Tunisia with scale bar $=40 \mathrm{~mm}$

local communities was considered by researchers to enlarge and improve attention in fisheries research, referred to as "local ecological knowledge", used to track geographical distribution of alien species in their new living area (AZZURRO et al., 2011). The description of these specimens in the present paper follows BELLO et al. protocol (2014) recommended for first records.

The first specimen of Scorpaena maderensis was collected on 28 June 2015, and the second on 17 August 2015, off Ras Jebel, city located in north eastern Tunisia $\left(37^{\circ} 15^{\prime} 27.00^{\prime \prime} \mathrm{N}\right.$ and

\begin{tabular}{|l|c|c|c|c|c|c|}
\hline References & \multicolumn{3}{l|}{ FSB Scor-mad 01 } & \multicolumn{3}{l|}{ FSB Scor-mad 02 } \\
\hline Measurements & $\mathbf{m m}$ & $\mathbf{\% T L}$ & $\mathbf{\% S L}$ & $\mathbf{m m}$ & $\mathbf{\% L T}$ & \%SL \\
\hline Total length & 125 & 100 & 119.0 & 132 & 100 & 120.0 \\
\hline Standard length & 105 & 84 & 100.0 & 110 & 83.3 & 100.0 \\
\hline Head length & 40 & 32 & 38.1 & 42 & 31.7 & 38.2 \\
\hline Orbit diameter & 10 & 8.0 & 9.5 & 11 & 8.3 & 10.0 \\
\hline Pre-orbital space & 12 & 9.6 & 11.4 & 12 & 9.1 & 10.9 \\
\hline Post-orbital space & 20 & 16 & 16.0 & 20 & 15.2 & 18.2 \\
\hline Dorsal fin length & 61 & 48.8 & 5.9 & 63 & 46.2 & 57.2 \\
\hline Pectoral fin length & 12 & 9.6 & 11.4 & 13 & 9.6 & 11.8 \\
\hline Pelvic fin length & 13 & 10.4 & 12.4 & 10 & 7.6 & 9.1 \\
\hline Anal fin length & 16 & 12.8 & 15.2 & 14 & 10.6 & 12.7 \\
\hline Caudal fin length & 11 & 8.8 & 10.5 & 10 & 7.6 & 9.1 \\
\hline Snout length & 11 & 8.8 & 10.5 & 11 & 8.3 & 10.0 \\
\hline Maximum body height & 40 & 32.0 & 38.1 & 38 & 28.9 & 34.5 \\
\hline Pre-dorsal fin length & 35 & 28.0 & 33.3 & 34 & 25.8 & 30.9 \\
\hline Pre-pectoral fin length & 36 & 28.8 & 34.3 & 39 & 29.6 & 35.5 \\
\hline Pre-pelvic fin length & 43 & 34.4 & 40.9 & 38 & 28.8 & 34.5 \\
\hline Pre-anal fin length & 73 & 58.4 & 69.5 & 74 & 56.1 & 67.2 \\
\hline Pectoral fin heigth & 30 & 24.0 & 28.6 & 30 & 22.7 & 27.3 \\
\hline Body depth & 25 & 20.0 & 23.8 & 22 & 16.7 & 20.0 \\
\hline
\end{tabular}

Table 1. Morphometric measurements in $\mathrm{mm}$ recorded from the specimens of Scorpaena maderensis captured off northern Tunisia 


\begin{tabular}{|c|c|c|c|}
\hline References & FSB scorp-mad 01 & FSB scorp-mad 02 & FSB scorp-mad 03 \\
\hline \multicolumn{4}{|l|}{ Fin rays } \\
\hline Dorsal & $\mathrm{XII}+10$ & $\mathrm{XII}+9$ & XI-XIII + 9-12 \\
\hline Anal & $\mathrm{III}+5$ & $\mathrm{III}+5$ & III + 4-5 \\
\hline Pelvic & $\mathrm{I}+5$ & $\mathrm{I}+5$ & $\mathrm{I}+5$ \\
\hline Pectoral & 16 & 14 & $14-16$ \\
\hline Caudal & 16 & 16 & - \\
\hline \multicolumn{4}{|l|}{ Head spines } \\
\hline Pre-orbital & 2 & 2 & 2 \\
\hline Sub-orbital & 2 & 2 & 2 \\
\hline Upper post-temporal & 1 & 1 & 1 \\
\hline Lower post-temporal & 1 & 1 & 1 \\
\hline Opercular & 2 & 2 & 2 \\
\hline Preopercular & 4 & 4 & $4-6$ \\
\hline Cleithral & 2 & 2 & 2 \\
\hline Supra-cleithral & 1 & 1 & 1 \\
\hline Nasal & 1 & 1 & 1 \\
\hline Pre-ocular & 1 & 1 & 1 \\
\hline Supra-ocular & 1 & 1 & 1 \\
\hline Post-ocular & 1 & 1 & 1 \\
\hline Tympanic & 1 & 1 & 1 \\
\hline Parietal & 1 & 1 & 1 \\
\hline Nucal & 1 & 1 & 1 \\
\hline Pterotic & 1 & 1 & 1 \\
\hline Sphenotic & 1 & 1 & 1 \\
\hline \multicolumn{4}{|l|}{ Skin flaps/tentacles } \\
\hline Nasal & 2 & 2 & 2 \\
\hline Mandibular & 0 & 2 & $0-8$ \\
\hline Supra-ocular & 2 & 2 & 2 \\
\hline \multicolumn{4}{|l|}{ Other counts } \\
\hline Lateral line scales & 45 & 45 & $45-51$ \\
\hline Gill rakers & 15 & 15 & 15 \\
\hline
\end{tabular}

Table 2. Meristic counts recorded from Scorpaena maderensis captured off northern Tunisia, compared with the same recorded from specimens captured off the south-eastern coast of Sicily (see LA MESA, 2005)

$10^{\circ} 09$ ' 44.03” E) (Fig. 1). Both specimens were captured by trammel nets at a depth of 18 $\mathrm{m}$ approximately, on rocky bottoms partially covered with algae, together with labrid and sparid species and black scorpionfish Scorpaena porcus.

All measurements were made to the nearest millimeter by using digital caliper, and weighed to the nearest 0.1 gram for total body (Table 1). Meristic characters, especially head spines, following LA MESA (2005) are summarized in Table 2 . The specimens were fixed in $10 \%$ buffered formaldehyde, preserved in $75 \%$ ethanol and deposited in the Ichthyological Collection of the Faculté de Sciences de Bizerte (Tunisia), receiving the catalogue numbers FSB Scor-mad 01 and FSB Scor-mad 02, respectively (Fig. 2).

\section{RESULTS AND DISCUSSION}

Both specimens were identified as Scorpaena maderensis via combination of the following characters: body robust, head large and spiny, snout as long as orbit diameter, $10-10.5 \%$ of standard length (SL), occipital pit absent, pores at symphysis of lower jaw separate and small, ctenoid scales on sides of body, chest and pectoral fin base with cycloid scales, head naked, 15 gill rakers (see Table 2). Colour of body dark, head brown, dorsal fin with dark blotches, pec- 
toral fins with dark spots, caudal with vertical dark strips.

Morphology, measurements, counts and colour are in total agreement with previous descriptions of Scorpaena maderensis by CADENAT (1943), TORTONESE (1975), HUREAU \& LITVINENKO (1986), DULČIĆ et al. (2003) and LA MESA (2005), and could be included among the species recorded in Tunisian ichthyofauna. S. maderensis can be distinguished from co-generic species occurring in theTunisian waters (BRADAI et al., 2004) by the absence of occipital pit.

Scorpaena maderensis is rather rare in the Mediterranean except for the Central Mediterranean (LA MESA, 2005) and rocky shallow bottoms from the Levant Basin (GOLANI et al., 2007), where substantial records were reported. Such scarcity in some Mediterranean regions could be explained by misidentifications with closely related species such as black scorpionfish $S$. porcus, according to LA MESA (2005). Additionally, basing on information locally provided by fishermen, specimens of $S$. maderensis reach small size and do not represent an economic interest. Therefore, they are not landed on fishing sites, where generally, only large specimens of scorpionids are taken into commercial consideration.

Scorpaena maderensis was first described from specimens caught off Madeira, deposited in the Ichthyological Collection of the Muséum National d'Histoire Naturelle de Paris (BLANC \& HUREAU, 1973). On the other hand, it appears from reports made by HUREAU \& LITVINENKO (1986), that the species is rather common in the eastern tropical Atlantic. It could be considered as a native species from this latter region, and a migration toward the Mediterranean through the Strait of Gibraltar remains a suitable hypothesis, which cannot be totally ruled out, although GOLANI et al. (2017) do not include $S$. maderensis among the herculean migrants found in this sea. Warming of the Mediterranean waters may increase the introduction of fish species previously unknown in this sea (BEN RAIIS LASRAM \& MOUILLOT, 2009), some of them are successfully established, and $S$. maderensis constitutes a good instance, and the frequency of its captures in the central Mediterranean allows to suggest that this region is the core of the repartition of the species throughout the entire sea.

\section{REFERENCES}

AZZURRO, E., P. MOSCHELLA \& F. MAYNOU. 2011. Tracking signals of change in Mediterranean fish diversity based on Local Ecological Knowledge. PLoS ONE 6: e24885.

BELLO, G., R. CAUSSE, L. LIPEJ \& J. DULČIĆ. 2014. A proposal best practice approach to overcome unverified and unverifiable «first records» in ichthyology. Cybium, 38(1): 9-14.

BEN RAIS LASRAM, F. \& D. MOUILLOT. 2009. Increasing southern invasion enhances congruence between endemic and exotic Mediterranean fish fauna. Biol. Inv., 11: 697-711.

BILECENOGLU, M., KAYA M., CIHANGIR B. \& E. ÅIÇEK. 2014. An updated check list of the marine fishes of Turkey. Turk. J. Zool., 38(4): 901-929.

BLANC, M. \& J.-C. HUREAU. 1973. Scorpaenidae. Check-list of the Fishes the Northeastern Atlantic and the Mediterranean . Vol. III. In:
J.C. Hureau \& Th. Monod (Editors). UNESCO, Paris, pp. 579-585.

BRADAI, M.N., J.P. QUIGNARD, A. BOUAIN, O. JARBOUI, A. OUANNES-GHORBEL, L. BEN ABDALLAH, J. ZAOUALI \& S. BEN SALEM. 2004. Ichtyofaune autochtone et exotique des côtes tunisiennes: recensement et biogéographie (Autochtonous and exotic fish species of the Tunisian coasts: Inventory and biogeography). Cybium, 28(4): 315-328.

CADENAT, J. 1943. Les Scorpaenidae de l'Atlantique et de la Méditerranée. Première note: le genre Scorpaena. (The Scorpaenidae from the Atlantic and the Mediterranean. First note: the genus Scorpaena). Rev. Trav. Off. scient.tech. Pêch. marit., 53(1-4): 525563.

DULČIĆ, J., PALLAORO A. \& S. MATIC. 2003. On the record of Madeira rockfish Scorpaena 
maderensis Valenciennes, 1833, in the eastern Adriatic. Annales, ser. Hist. nat., 13(1): 19-22.

ESCHMEYER, W.N. 1969. A systematic review of the scorpionfishes of the Atlantic Ocean (Pisces, Scorpaenidae). Occ. Pap. Calif. Acad. Sci., 79: 1-130.

FALZON, M.-A. 2011. First records of Scorpaena maderensis (Pisces Scorpaenifomes Scorpaenidae) in inshore Maltese waters. Naturalista sicil., 35(3-4): 419-423.

GOLANI, D., L. ORSI-RELINI L., E. MASSUTI E. \& J.-P. QUIGNARD, J. DULČIĆ \& E. AZZURRO. 2017. CIESM Atlas of Exotic Fishes in the Mediterranean Sea: alien fishes, invasive fishes. World Wide Web electronic publication. http// www.ciesm.org/atlas/appendix1. $\mathrm{html}$, version $01 / 2017$.

GOLANI, D., R. REEF-MOTRO, S. EKSHTEIN, A. BARANES \& A. DIAMANT. 2007. Ichthyofauna of the rocky coastal littoral of the Israeli
Mediterranean, with reference to the paucity of Red Sea (Lessepsian) migrants in this habitat. Mar. Biol. Res. 3: 333-341.

HUREAU, J.C. \& N.I. LITVINENKO. 1986. Scorpaenidae. Fishes of the Northwestern Atlantic and the Mediterranean . Vol. III. In: J.P. Whitehead, M.L. Bauchot, J.C. Hureau, J. Nielsen $\&$ E. Tortonese (Editors). UNESCO, Paris, pp. 1211-1229.

KOLOMBATOVIĆ, J. 1904. Contribuzioni alla fauna dei vertebrati della Dalmazia (Contribution to the fauna of Vertebrates from Dalmatia). Glas. Hrv. Narav. drustva, 15: 182-191.

LA MESA, G. 2005. A revised description of Scorpaena maderensis (Scorpaenidae) by means of meristic and morphometric analysis. J. Mar. Biol. Ass.U.K., 85(5): 1263-1270.

TORTONESE, E. 1975. Osteichthyes (Pesci ossei) Parte prima (Osteichthyes (Bony fishes) Second part). In: Fauna d'Italia, p. 636. 


\title{
Prvi nalaz bodečnjaka malog, Scorpaena maderensis (Osteichthyes: Scorpaenidae), s tuniske obale (središnje Sredozemlje)
}

\author{
Sihem RAFRAFI-NOUIRA*, Daniel GOLANI i Christian CAPAPÉ \\ *Kontakt, e-pošta: sihem.rafrafi@yahoo.fr
}

\section{SAŽETAK}

Autori iznose prve zapise vrste bodečnjaka malog Scorpaena maderensis Valenciennes, 1833. s tuniske obale (središnji dio Sredozemlja). Opisani su uzorci, uključujući morfometrijska i meristička mjerenja. Razmatra se i raspravlja podrijetlo vrste u novom životnom okolišu.

Ipak, ovi novi nalazi potvrđuju uspostavljanje održive populacije $S$. maderensis u središnjem dijelu Sredozemnog mora.

Ključne riječi: Osteichthyes, Scorpaenidae, Scorpaena maderensis, Tunis, populacija, središnji dio Sredozemnog mora 